\title{
Factors Affecting Soil Acidity in Hungary
}

\author{
${ }^{1}$ B. SIMON, ${ }^{1}$ E. MICHÉLI, ${ }^{2}$ G. E. VAN SCOYOC and ${ }^{2}$ W. W. MCFEE \\ ${ }^{1}$ Szent István University, Department of Soil Science and Agricultural Chemistry, \\ Gödöllő (Hungary) and ${ }^{2}$ Purdue University, Department of Agronomy, West Lafayette
}

(USA)

Acidity of soils is an important soil characteristic, as it may indicate soil degradation and can result in poor soil quality. Organic and inorganic soil colloids, with their large specific surface area, play an important role in controlling soil acidification. Soil acidification has been studied in Hungary in field experiments following different amounts of fertilizer applications. Several authors found acidity increase due to the applied fertilizers (DEBRECZENI \& PÉTERFALVI, 1994; ZSIGRAI, 1995). The importance of soil acidification was also emphasized at the World Congress of Soil Science held in Montpellier, France, in 1998. 23 oral and poster presentations were given about acidification.

The Hungarian Soil Information and Monitoring System (TIM) is a national soil conservation programme with the purpose of determining and monitoring changes in soil quality. It is a subsystem of the Environmental Information and Monitoring System established in 1991. The observation network (consisting of 1237 points on the whole area of Hungary) has sampling sites on agricultural (865) and forestry sites (183) and on environmentally sensitive areas (189) (TIM, 1995). Soil and groundwater samples are taken annually between 15 September-15 October. Single point samples are collected from approximately the same sites (within a $50 \mathrm{~m}$ circle) annually. Soil properties are tested for changes in time: in 1-, 3- or 6-year intervals, depending on the property examined (TIM, 1995).

The objectives of this study were to (1) determine the acidity status at selected sites of the TIM network, (2) examine the spatial variability of surface $\mathrm{pH}$, (3) examine acidification tendencies in the studied Hungarian soils, (4) examine soil acidity in relation to soil forming factors, such as parent material, annual rainfall, and native vegetation, and (5) relate acidity characteristics to soil properties such as organic matter, cation exchange capacity, and mineralogical composition.

Correspondence to: Barbara SIMON, Szent István University, Faculty of Agricultural and Environmental Sciences, Department of Soil Science and Agricultural Chemistry, H-2301 Gödöllö, Páter K. u. 1. Hungary. E-mail: Simonb@fau.gau.hu 


\section{Material and Methods}

Site selection and sampling procedure

Five soil sites with varying $\mathrm{pH}$ values were examined for this study as listed in Table 1. Four of these sites (designated by the TIM code in Table 1) were selected from the TIM database.

Table 1

The U.S. Soil Taxonomy names, parent materials, vegetation and precipitation of the sites

\begin{tabular}{|c|c|c|c|c|}
\hline $\begin{array}{c}\text { U.S. Soil } \\
\text { Taxonomy }\end{array}$ & $\begin{array}{l}\text { Location } \\
\text { (TIM code) }\end{array}$ & Parent material & Vegetation & $\begin{array}{l}\text { Precipitation } \\
(\mathrm{mm})\end{array}$ \\
\hline $\begin{array}{l}\text { Typic } \\
\text { Haplustalfs }\end{array}$ & $\begin{array}{c}\text { Oltárc } \\
\text { (E 6120) }\end{array}$ & Loess & Beech, oak & $750-800$ \\
\hline $\begin{array}{l}\text { Dystric } \\
\text { Ustochrepts }\end{array}$ & $\begin{array}{l}\text { Velem } \\
\text { (I 0218) }\end{array}$ & $\begin{array}{l}\text { Metamorphic } \\
\text { schist }\end{array}$ & Locust & $750-800$ \\
\hline $\begin{array}{l}\text { Typic } \\
\text { Ustochrepts }\end{array}$ & $\begin{array}{l}\text { Gödöllö } \\
\text { (E 0213) }\end{array}$ & $\begin{array}{c}\text { Aeolian } \\
\text { sand }\end{array}$ & Locust & $550-600$ \\
\hline $\begin{array}{l}\text { Typic } \\
\text { Medisaprists }\end{array}$ & $\begin{array}{l}\text { Zalavár } \\
\text { (S 4920) }\end{array}$ & Peat & Marsh & $650-700$ \\
\hline $\begin{array}{l}\text { Typic } \\
\text { Haplustalfs }\end{array}$ & Karád & Loess & $\begin{array}{l}\text { Austrian oak, } \\
\text { maple }\end{array}$ & $650-700$ \\
\hline
\end{tabular}

Soil samples, consisting of 5-6 composite subsamples, were taken from each horizon of the selected profiles for chemical, physical and mineralogical analyses.

To determine the spatial variability of surface $\mathrm{pH}$, twelve point samples were taken at two depths $(0-5 \mathrm{~cm}$ and $5-20 \mathrm{~cm})$ within a $10 \times 10$ meter area adjacent to the four TIM sampling profiles (Oltárc, Velem, Gödöllö, Zalavár) and the Karád site. The purpose of these measurements was to determine the number of samples needed to be taken in order to produce a reliable estimate from year to year. Acidity $\left[\mathrm{pH}\left(\mathrm{H}_{2} \mathrm{O}\right)\right.$ and $\left.\mathrm{pH}(\mathrm{KCl})\right]$ was measured, then the results were compared with the $\mathrm{pH}$ values of the TIM profile at the corresponding depth.

\section{Analytical procedures}

The $\mathrm{pH}\left(\mathrm{H}_{2} \mathrm{O}\right)$ and $\mathrm{pH}(\mathrm{KCl})$ were determined electrometrically with a soil to liquid ratio of 1:2.5. Hydrolytic acidity $\left(\mathrm{HAC}_{1}\right)$, according to KAPPEN (1929), is the amount of acidity which can be liberated by Ca-acetate $[0.5 \mathrm{M}$ $\left.\mathrm{Ca}\left(\mathrm{CH}_{3} \mathrm{COO}\right)_{2}\right]$. Exchangeable acidity $\left(\mathrm{EAC}_{1}\right)$ is the amount of acidity $\left(\mathrm{Al}^{3+}\right.$ and $\mathrm{H}_{3} \mathrm{O}^{+}$ions) that can be liberated by a neutral salt solution $[1 \mathrm{M} \mathrm{KCl}]$ (BUZÁs, 1988). The cation exchange capacity (CEC) was measured by using 
the unbuffered salt extraction method, a modification of the procedure described by GROVE et al. (1982). Soil organic matter (OM) was determined by the Walkley-Black method (WALKLEY, 1947). The E4/E6 ratios were determined using STEVENSON's (1994) method. The ratio of absorbances of the alkali extracted organic matter is measured at $465 \mathrm{~nm}$ and $665 \mathrm{~nm}$ on a Hitachi U2001 Spectrophotometer (STEVENSON, 1994). The total calcium carbonate content was determined by the Scheibler method (BUZÁs, 1988). The $\mathrm{CaCO}_{3}$ was destroyed by hydrochloric acid $(10 \% \mathrm{HCl})$ and the volume of the produced $\mathrm{CO}_{2}$ gas was measured. For mineralogical analysis, particle size fractionation was performed using the modified procedures described by JACKSON (1969). The following fractions were examined by X-ray diffraction (XRD): fine silt (5-2 $\mu \mathrm{m})$, coarse clay $(2-0.2 \mu \mathrm{m})$ and fine clay $(<0.2 \mu \mathrm{m})$ fractions.

\section{Statistical Analyses}

Mean, standard deviation, standard error, and 95\% confidence interval were determined for the spatial variability study of the surface $\mathrm{pH}$ data. Analytical data were analyzed statistically by stepwise regression using SAS Software (SAS Inst. Inc., 1999).

\section{Results and Discussion}

\section{Spatial variability of surface $\mathrm{pH}$ samples}

Based on the spatial variability study it was found that in $61 \%$ of the cases the TIM and the Karád soil profile $\mathrm{pH}$ value was within the $95 \%$ confidence interval around the mean of the 12 samples taken within the $10 \mathrm{~m} \times 10 \mathrm{~m}$ grid.

\section{Precipitation, parent material, and $\mathrm{pH}$ values}

Two of the examined sites, Oltárc and Velem, are located in Western Hungary, where the annual precipitation is the highest, $750-800 \mathrm{~mm}$. The $\mathrm{pH}$ values at these two sites were different, probably due to the different parent materials, which were loess in case of the Oltárc soil, and metamorphic schist in the Velem soil. The metamorphic schist parent material, with a low base status supposedly contributed to the lower $\mathrm{pH}\left(\mathrm{H}_{2} \mathrm{O}\right)$ values in the Velem soil, ranging from 4.61 to 5.09 throughout the profile (Table 2). Weathering might have been enhanced by the high precipitation that this site received annually. In the Oltárc soil the $\mathrm{pH}\left(\mathrm{H}_{2} \mathrm{O}\right)$ values were higher, ranging from 5.07 to 5.60 (Table 2), since the high amount of precipitation at this site might have been compensated by the calcareous loess parent material. The average calcium carbonate content of loess is about 10-15\% (STEFANOVITS et al., 1999), which was leached out during the soil formation process to varying depths in most soils in Hungary. 
Table 2

Chemical analyses of the soils at the study sites

\begin{tabular}{|c|c|c|c|c|c|c|c|c|c|}
\hline $\begin{array}{l}\text { Depth } \\
(\mathrm{cm})\end{array}$ & Hor & $\begin{array}{c}\mathrm{pH} \\
\left(\mathrm{H}_{2} \mathrm{O}\right)\end{array}$ & $\begin{array}{c}\mathrm{pH} \\
(\mathrm{KCl})\end{array}$ & $\begin{array}{c}\mathrm{OM} \\
\%\end{array}$ & $\begin{array}{c}\mathrm{CEC} \\
\mathrm{cmol} / \mathrm{kg}\end{array}$ & $\mathrm{HAC}_{1}$ & $\mathrm{EAC}_{1}$ & E4/E6 & $\begin{array}{c}\text { Clay } \\
\%\end{array}$ \\
\hline \multicolumn{10}{|c|}{ Karád } \\
\hline $0-5$ & A & 5.18 & 4.19 & 5.80 & 11.7 & 7.8 & 0.4 & 7.0 & 18.96 \\
\hline $5-20$ & $\mathrm{E}$ & 4.96 & 3.29 & 0.91 & 6.70 & 6.1 & 3.9 & 5.4 & 19.01 \\
\hline $20-45$ & Bt1 & 5.43 & 3.52 & 0.54 & 10.2 & 3.5 & 1.7 & 5.3 & 25.31 \\
\hline $45-70$ & Bt2 & 5.69 & 3.80 & 0.22 & 16.2 & 2.5 & 0.6 & 6.8 & 30.98 \\
\hline $70-100$ & $\mathrm{C}$ & 5.82 & 4.06 & 0.32 & 10.3 & 1.8 & 0.3 & 7.4 & 24.77 \\
\hline \multicolumn{10}{|c|}{ Oltárc } \\
\hline $0-5$ & A & 5.50 & 4.63 & 3.10 & 11.0 & 4.9 & 0.2 & 7.0 & 19.94 \\
\hline $5-20$ & E & 5.16 & 3.56 & 0.72 & 7.00 & 3.8 & 1.5 & 5.4 & 23.52 \\
\hline $30-40$ & Bt1 & 5.21 & 3.55 & 0.53 & 13.2 & 3.6 & 1.8 & 5.8 & 36.16 \\
\hline $40-70$ & Bt2 & 5.07 & 3.42 & 0.34 & 13.4 & 4.3 & 2.8 & 6.3 & 40.92 \\
\hline $80-120$ & $\mathrm{C}$ & 5.60 & 3.72 & 0.16 & 14.2 & 2.4 & 0.8 & 6.6 & 32.70 \\
\hline \multicolumn{10}{|c|}{ Velem } \\
\hline $0-5$ & A & 4.97 & 3.81 & 4.75 & 8.44 & 8.6 & 0.8 & 6.1 & 25.49 \\
\hline $5-20$ & $\mathrm{E}$ & 4.61 & 3.47 & 1.28 & 5.46 & 6.4 & 3.1 & 5.5 & 19.55 \\
\hline $20-40$ & B & 4.81 & 3.43 & 0.90 & 4.93 & 5.2 & 2.6 & 4.7 & 22.70 \\
\hline $40-70$ & $\mathrm{BC}$ & 5.08 & 3.51 & 0.55 & 5.30 & 4.3 & 1.4 & 4.6 & 23.33 \\
\hline $70-100$ & $\mathrm{C}$ & 5.09 & 3.30 & 0.33 & 5.14 & 3.5 & 1.5 & 4.9 & 23.17 \\
\hline \multicolumn{10}{|c|}{ Gödöllö } \\
\hline $0-5$ & A & 7.02 & 6.39 & 1.56 & 13.08 & 1.2 & - & 7.0 & 20.51 \\
\hline $5-20$ & $\mathrm{AB}$ & 7.54 & 6.69 & 1.01 & 9.82 & 0.7 & - & 6.5 & 11.56 \\
\hline $20-40$ & B & 7.57 & 6.55 & 0.57 & 8.13 & 0.6 & - & 5.3 & 17.66 \\
\hline $40-60$ & $\mathrm{BC}$ & 7.66 & 6.34 & 0.28 & 5.63 & 0.6 & - & 5.8 & 8.470 \\
\hline $60-100$ & $\mathrm{C}$ & 8.00 & 6.47 & 0.01 & 2.90 & 0.5 & - & 5.8 & 7.700 \\
\hline \multicolumn{10}{|c|}{ Zalavár } \\
\hline $0-20$ & H1 & 6.76 & 6.09 & 23.12 & 55.46 & 2.2 & 0.1 & 7.8 & - \\
\hline $20-40$ & $\mathrm{H} 2$ & 6.13 & 5.29 & 24.16 & 63.83 & 5.9 & 0.1 & 8.2 & - \\
\hline $40-60$ & $\mathrm{H} 3$ & 5.71 & 5.00 & 26.12 & 68.05 & 9.8 & 0.1 & 7.9 & - \\
\hline $60-80$ & $\mathrm{H} 4$ & 5.07 & 4.62 & 24.20 & 50.36 & 16.8 & 0.3 & 8.1 & - \\
\hline $90-110$ & H5 & 4.86 & 4.48 & 19.11 & 37.78 & 16.7 & 0.5 & 7.3 & - \\
\hline
\end{tabular}

The Karád soil is East from the two previous sites, and located in a region that receives lower amounts of precipitation, about $650-700 \mathrm{~mm}$ annually. The parent material in the Karád soil is loess. The $\mathrm{pH}\left(\mathrm{H}_{2} \mathrm{O}\right)$ values of this site are relatively low, ranging from 4.96 to 5.82 (Table 2), fairly similar to the Oltárc soil, which was also developed on loess parent material.

The Zalavár soil is located East from Lake Balaton, in a region that receives about $650-700 \mathrm{~mm}$ precipitation annually. The parent material of the Zalavár soil is peat. It is located in a depressional area, thus the water table fluctuates 
seasonally - unlike the forest soils, where the downward water movement is dominant, enhancing the leaching processes. This might be the reason the $\mathrm{pH}\left(\mathrm{H}_{2} \mathrm{O}\right)$ of this organic soil - which ranges from 4.86 to 6.76 (Table 2) shows a different $\mathrm{pH}$ profile than was observed in the forest soils.

The Gödöllö soil is located in the North-central part of Hungary, where the annual precipitation is only about $550-600 \mathrm{~mm}$. The parent material is aeolian sand at this site. The $\mathrm{pH}\left(\mathrm{H}_{2} \mathrm{O}\right)$ values were the highest among all the examined soils, ranging from 7.02 to 8.00 (Table 2), probably as a result of the lower amount of precipitation, thus less intense weathering processes. This site has been disturbed, which might have also been the reason for these relatively high $\mathrm{pH}$ values.

\section{Cation exchange capacity (CEC) and organic matter (OM)}

The surface OM content is contributed to the relatively high CEC value at the surface for both the Karád and the Oltárc soils, but the correlation of CEC and $\mathrm{OM}$ was not significant. In the next horizon, which is a leached horizon, the amount of OM and the CEC value decreased. However, the decrease of OM in the $\mathrm{B}$ horizon did not result in the lowering of the CEC because of the increasing amounts of clay in the lower layers (Table 2).

The OM showed significant correlation with the CEC in case of the Velem $\left(\mathrm{r}^{2}=0.9630^{* *}\right)$ and the Gödöllö soils $\left(\mathrm{r}^{2}=0.9738^{* *}\right)$. The CEC decreased with the decrease in OM (Table 2).

The surface horizon in the Zalavár soil had a relatively high charge per mass compared to the lower horizons (Table 2), which might be due to the fresh OM accumulated in the top horizon.

\section{Hydrolytic $\left(H A C_{I}\right)$ and exchangeable acidity $\left(E A C_{l}\right)$}

The following tendency was found in the different horizons for hydrolytic $\left(\mathrm{HAC}_{1}\right)$ and exchangeable $\left(\mathrm{EAC}_{1}\right)$ acidity of all mineral soils (Karád, Oltárc, Velem, Gödöllö) (Table 2). In the top horizon $(0-5 \mathrm{~cm})$, the $\mathrm{HAC}_{1}$ value was the highest due to the highest amount of OM content. The OM provides high $\mathrm{pH}$-dependent negative charge at the 8.2 buffered $\mathrm{pH}$ of the determination. In the same horizon, the $\mathrm{EAC}_{1}$ value was very low because the $\mathrm{Al}^{3+}$ ions are likely complexed with the $\mathrm{OM}$, so the neutral $\mathrm{KCl}$ solution cannot exchange these $\mathrm{Al}^{3+}$ ions. In the underlying horizon $(5-20 \mathrm{~cm})$, the $\mathrm{HAC}_{1}$ value decreased to some extent, but still remained high. The $\mathrm{EAC}_{1}$ value increased dramatically due to the low OM content, and the high unbuffered acidity, except in the organic soil (Zalavár) and where the soil $\mathrm{pH}$ was near neutral (Gödöllö). The $\mathrm{HAC}_{1}$ value decreased down the profile as the $\mathrm{pH}$ increased. In the $\mathrm{B}$ horizons no clear tendency was found for $\mathrm{EAC}_{1}$, probably because of the varying amount and type of mineral colloids (FILEP \& FILEP, 1999). 
The $\mathrm{HAC}_{1}$ values showed an increasing tendency toward the lower horizons of the Zalavár soil (Table 2). This is probably because the OM content was increasing towards these two horizons, giving a higher amount of exchange sites where high amount of $\mathrm{H}^{+}$ions were held. The $\mathrm{EAC}_{1}$ values were fairly low throughout the profile as they are mostly associated with permanent charges.

\section{The E4/E6 ratios}

We found that the E4/E6 ratio was high in the surface horizon, and then decreased in the $\mathrm{B}$ horizon, and increased again in the $\mathrm{C}$ horizon in the mineral soils (Table 2). The E4/E6 ratio was 7 in the $0-5 \mathrm{~cm}$ layer for the Karád, Oltárc, and Gödöllö soils, and 6.1 in the Velem soil, which is fairly high and suggests lower molecular weight, fresh OM. Further down the profile lower ratios were found, suggesting the presence of more condensed, humic acids with higher molecular weight. The increase in the E4/E6 ratio in the lower horizons might be due to the migration of the water soluble light fraction of the organic matter.

The E4/E6 ratio in the Zalavár soil (Table 2) was relatively uniform throughout the profile and had values above 7.0, indicating lower molecular weight and less condensation. This is likely due to the incomplete oxidation of these organic residues due to poor drainage conditions.

\section{Mineralogy discussion of the Karád, Oltárc and Gödöllö sites}

The mineralogy of the two Typic Haplustalfs soils (Karád and Oltárc) was very similar to each other with the same kind and approximately the same amount of minerals present (Table 3). The mineralogy of the Typic Ustochrepts soil (Gödöllö) was also similar to that of Karád and Oltárc soils but the proportion of these minerals was slightly different. This result was somewhat expected since the soils at the Karád and the Oltárc site were developed on loess, while the soil at the Gödöllő site was developed on aeolian sand deposit.

At these three sites there was an increase in the amount of mica in the lower horizon as compared to the upper horizon due to higher acidity and more intense weathering in the A horizon, which coincides with other findings in the literature. In soils developed from uniform parent materials, the abundance of micaceous minerals in all size fractions commonly increases with depth (SCHUMACHER \& PERKINS, 1987; STOLT et al., 1991). Since the $\mathrm{pH}\left(\mathrm{H}_{2} \mathrm{O}\right)$ of the soils at the Karád and the Oltárc sites is fairly acidic throughout the profile, ranging from 4.96 to 5.8 , it encourages the dissolution of layer silicates because protons penetrate the structure at crystal edges and bind with oxygen anions that are shared between the tetrahedral and octahedral sheets (NAGY, 1995). On the contrary, in the Gödöllö soil the mica component is present in a higher amount relative to the vermiculite or HIV components according to the XRD patterns in both depths. This is probably due to the higher $\mathrm{pH}\left(\mathrm{H}_{2} \mathrm{O}\right.$ ) (ranging from 7.02 to 
8.00) at this site in comparison to the two other sites, thus it probably has a less intense weathering process, therefore the majority of the mica component has yet not weathered to vermiculite as it had in the two other soils.

The smectite content increased in the lower horizon as compared to the topsoil in these three samples, as evidenced by the Mg-glycerinated treatment in the fine clay fraction. STEFANOVITS (1989) found that due to the lessivation process smectites migrate more easily from the topsoil into the accumulation horizon, leading to significant differences in the clay mineral compositions of the leaching and accumulation horizons.

\section{Mineralogy discussion of the Velem site}

The soil at the Velem site was developed on metamorphic schist, which was indicated by the intense peak of the clintonite mineral, and the different proportions of other minerals in the sample, as compared to the three other soils at Karád, Oltárc and Gödöllő sites. Clintonite is present in major amounts in the coarse clay and the fine silt fractions, and it usually occurs with talc in chlorite schist. The low base status of this parent material contributed to the acidic $\mathrm{pH}\left(\mathrm{H}_{2} \mathrm{O}\right)$ values found in this soil, ranging from 4.61 to 5.09 throughout the profile. These $\mathrm{pH}$ values are likely a result of intense weathering processes on the parent material. However, the mica content was relatively high in this

Table 3

Clay mineralogy in order of estimated decreasing abundance based on two sample depths of each location

\begin{tabular}{|c|c|c|}
\hline Soil sites & $\begin{array}{l}\text { Frac- } \\
\text { tions }\end{array}$ & Minerals, decreasing in abundance \\
\hline Karád & $\begin{array}{l}\mathrm{FSi} \\
\mathrm{CC} \\
\mathrm{FC}\end{array}$ & $\begin{array}{l}\text { vermiculite, mica, kaolinite, chlorite, quartz, rutile, feldspar } \\
\text { hydroxy-interlayered vermiculite (HIV), mica, kaolinite, chlorite } \\
\text { and quartz } \\
\text { smectite, kaolinite and mica }\end{array}$ \\
\hline Oltárc & $\begin{array}{l}\text { FSi } \\
\mathrm{CC} \\
\mathrm{FC}\end{array}$ & $\begin{array}{l}\text { vermiculite, mica, kaolinite, chlorite, quartz, rutile, feldspar } \\
\text { HIV, mica, kaolinite, chlorite and quartz } \\
\text { smectite, kaolinite and mica }\end{array}$ \\
\hline Gödöllő & $\begin{array}{l}\text { FSi } \\
\mathrm{CC} \\
\mathrm{FC}\end{array}$ & $\begin{array}{l}\text { mica, kaolinite, vermiculite, chlorite, quartz, rutile, feldspar } \\
\text { mica, HIV, kaolinite, chlorite and quartz } \\
\text { smectite, kaolinite and mica }\end{array}$ \\
\hline Velem & $\begin{array}{l}\mathrm{FSi} \\
\mathrm{CC} \\
\mathrm{FC}\end{array}$ & $\begin{array}{l}\text { mica, vermiculite, clintonite, kaolinite and quartz } \\
\text { mica, vermiculite, clintonite } \\
\text { hydroxy-interlayered smectite (HIS), kaolinite and mica }\end{array}$ \\
\hline
\end{tabular}

Fine silt - FSi $(2-5 \mu \mathrm{m})$; coarse clay - CC $(0.2-2 \mu \mathrm{m})$; and fine clay $-\mathrm{FC}(<0.2 \mu \mathrm{m})$ 
sample according to the XRD results. The mica probably originated from the partially weathered parent material, as mica is among the most common minerals in schists with quartz and feldspars (SPENCER, 1983). Based on the field observations, we noticed that at this site, in especially the lower horizons, the soil matrix was mixed with a lot of unweathered, and partially weathered parent material.

\section{Summary and Conclusions}

The Typic Haplustalfs soils (Karád and Oltárc) and the Typic Ustochrepts (Gödöllö) are developed on loess, and on aeolian sand parent material, under forest vegetation, resp. The Dystric Ustochrepts (Velem) soil formed on metamorphic schist parent material and had forest vegetation, while the Typic Medisaprists (Zalavár) soil developed on peat parent material and had marsh vegetation.

Based on this study the spatial variability of surface $\mathrm{pH}$ samples indicate that the TIM sampling procedure should be improved. Ten to thirty samples must be collected at each site to be able to monitor changes of $0.2 \mathrm{pH}$ units. If only one sample is taken at each site yearly, spatial difference in $\mathrm{pH}$ or other parameters are likely to obscure differences which may be occurring over time.

The colloidal composition (organic matter and clay minerals), influenced by parent material, vegetation, and precipitation, showed a close relationship with the acidity factors, such as $\mathrm{pH}, \mathrm{HAC}_{1}$ and $\mathrm{EAC}_{1}$ values. The $\mathrm{pH}$ values were the lowest in the Velem and Oltárc soils where the annual precipitation was the highest $(750-800 \mathrm{~mm})$, and in the Karád soil, where the annual precipitation was $650-700 \mathrm{~mm}$. The Gödöllö soil had the highest $\mathrm{pH}$ values, probably due to the lowest amount of rainfall $(550-600 \mathrm{~mm})$ and the disturbance. The Zalavár soil had fairly high $\mathrm{pH}$ throughout the profile probably due to a fluctuating water table.

The $\mathrm{HAC}_{1}$ and $\mathrm{EAC}_{1}$ values were the highest in the Velem soil when compared to the other mineral soils. The $\mathrm{pH}$ values were the lowest at this site. The $\mathrm{HAC}_{1}$ and $\mathrm{EAC}_{1}$ values were lower in the other three forest soils, at the Karád, Oltárc, and Gödöllö sites. The Zalavár soil had fairly high $\mathrm{HAC}_{1}$ values in the $\mathrm{H} 3, \mathrm{H} 4$ and $\mathrm{H} 5$ horizons, probably due to the very high OM content, which provided a lot of $\mathrm{H}^{+}$ions that can dissociate from the exchange sites.

The E4/E6 ratios were closely related to the decomposition or humification rate in the upper and the subsurface horizons with accumulation of low molecular weight soluble fraction in the deeper horizon.

The mineralogical analysis showed similar compositions for the soils developed on loess (Karád and Oltárc), or aeolian sand (Gödöllö), where the major minerals were vermiculite, mica, kaolinite, and chlorite. A different mineral 
composition (mica, vermiculite, clintonite, and kaolinite) was observed for the Velem site, where the parent material was metamorphic schist.

The four mineral soils are forest soils, with a predominant downward water movement, thus with fairly intensive leaching process. However, there was a distinct difference among the soils formed on loess (Karád and Oltárc), or aeolian sand (Gödöllö), and the soil (Velem) developed on metamorphic schist parent material. The soils at the Karád, Oltárc, and the Gödöllö sites were less acidified, with higher $\mathrm{pH}$, and lower $\mathrm{HAC}_{1}$, and $\mathrm{EAC}_{1}$ values as compared to the Velem soil, even if the precipitation was very high. The calcareous loess parent material probably compensated for the higher precipitation and the resulting leaching process at the Karád and the Oltárc sites. The Gödöllő soil received a very low amount of precipitation, which resulted in a low degree of weathering, with higher $\mathrm{pH}$, and lower $\mathrm{HAC}_{1}$, and $\mathrm{EAC}_{1}$ values. However, the metamorphic schist parent material probably contributed to a lower $\mathrm{pH}$ and lower buffering of the developing soil.

Based on the chemical and physical analyses, we concluded that among the soil forming factors, precipitation and parent material had the greatest influence on the acidity characteristics of the examined soils. The parent material influenced the mineralogy of the developing soil, which then influenced the $\mathrm{pH}$, $\mathrm{HAC}_{1}, \mathrm{EAC}_{1}$, and CEC values of the soil. In order to substantiate these tendencies more samples from a wider array of geological regions are needed.

Key words: acidity, cation exchange capacity, Hungary

\section{References}

BuZÁs, I. (Ed.) 1988. Laboratory Manual for Soil Analysis 2. (In Hungarian.) Mezögazdasági Kiadó. Budapest

Debreczeni, B. \& PÉTeRfalvi, B., 1994. The effect of long-term fertilization on acidification of OMTK soils. In: DEBRECZENI, B.: Fertilization Experiments 19601990. (In Hungarian) 118-121. Akadémiai Kiadó. Budapest.

FiLEP, Gy. \& FiLEP, T., 1999. Characterization of types of potential acidity. (In Hungarian) Agrokémia és Talajtan. 48.33-48.

Grove, J. H., Fowler, C. S. \& Sumner, M. E., 1982. Determination of the charge character of selected acid soils. Soil Sci. Soc. Am. J. 46. 32-38.

JACKSON, M. L., 1969. Soil Chemical Analysis - Advanced Course. $2^{\text {nd }}$ edition. Dept. of Soil Science, Univ. of Wisconsin. Madison, Wis.

KAPPEN, H., 1929. Die Bodenaziditat. Springer Verlag. Berlin.

NAGY, K. L., 1995. Dissolution and precipitation kinetics of sheet silicates. In: Chemical Weathering of Silicate Minerals. (Eds.: White, A. F. \& BRANTLEY, S. L.) Reviews in Mineralogy, Vol. 31. 172-233. Mineralogical Society of America. Washington, D. C.

SAS/STAT User's Guide, SAS Institute Inc. Version 8. Cary, NC: SAS Institute Inc., 1999. 
SCHUMACHER, B. R. \& Perkins, H. F., 1987. Soil genesis in a developmental sequence of soils formed in sillimanite mica schist residuum. Soil Sci. Soc. Am. J. 51. 12381242.

Spencer, E. W., 1983. Physical Geology. Addison-Wesley Publ. Co., Inc. Reading.

StefAnOVITS, P., 1989. Map of clay mineral associations in Hungarian soils. Agrokémia és Talajtan. 38. 790-799.

Stefanovits, P., Filep, Gy. \& Füleky, Gy., 1999. Soil Science. (In Hungarian.) Mezőgazda Kiadó. Budapest.

Stevenson, F. J., 1994. Humus Chemistry. Genesis, Composition, Reaction. $2^{\text {nd }}$ edition. John Wiley and Sons. Toronto.

Stolt, M. H., BAKER, J. C. \& Simpson, T. W., 1991. Micromorphology of the soilsaprolite transition zone in Hapludults of Virginia. Soil Sci. Soc. Am. J. 55. 1067 1075.

TIM, 1995. The Hungarian Soil Information and Monitoring System (TIM) 1. Methodology. (In Hungarian.) Ministry of Agriculture. Budapest.

WALKLEY, A., 1947. A critical examination of a rapid method for determining organic carbon in soils: Effect of variations in digestion conditions and of inorganic soil constituents. Soil Sci. 63. 251-263.

ZsigRAI, GY., 1995. The effect of long-term fertilization on the chemical composition of a chernozem soil. (In Hungarian.) Agrokémia és Talajtan. 44. 337-346. 